\title{
Review of Legal Protection of Indonesia in Australia Tapping Case
}

\section{Hanna Wijaya ${ }^{1}$, Yohanes Firmansyah ${ }^{2 *}$, Yana Sylvana ${ }^{3}$, Michelle Angelika $\mathrm{S}^{4}$ ${ }^{1234}$ Health Law Postgraduate Student, Pembangunan Negeri Veteran Jakarta \\ University}

\section{Corresponding Authors:}

1'hanwijaya08@gmail.com, 2yohanesfirmansyah28@gmail.com, ${ }^{3}$ sylvanayana@gmail. com, ${ }^{4}$ michelleangelika111@gmail.com

Article History:

Submit:

2021-12-30

Publish:

2022-02-28

\section{Abstract}

Several facts show that Australia has done several times wiretapping efforts against Indonesia. It is generally known that action tapping is an act of collecting information in secret diplomatic relations of a country. This journal is meant for analyzing the principle of the prohibition of wiretapping in the National Law, legal protection, and legal remedies that can be taken by Indonesia in the case of wiretapping. The research method used in this study is juriditve normative. This research analyzes relevant international treaties, case approaches, legal concept analysis approaches, and comparative approaches. The results of the study legally tapping is prohibited by law and international human rights based on the Universal Declaration of Human Rights (UDHR) in 1948, the International Covenant on Civil and Political Rights (ICCPR) in 1966, the European Convention for the Protection of Human Rights and Fundamental Freedoms (1958) and the 1961 Vienna Convention. 
While in the national law, the prohibition of tapping is provided in Article 28G paragraph (1) of the 1945 Constitution, Article 32 of law No. 39 of 1999, Article 40 of Law No. 36 of 1999, Article 31 paragraph (1) of Law No. 11 of 2008, and Article 31 paragraph (2) of Law No. 11 the Year 2008. concluded, juridically tapping is an act prohibited under international law and human rights In international law, Indonesian national law prohibits wiretapping. Indonesia has signed the Code of Conduct on Framework for Security Cooperation to prevent wiretapping. Besides, Indonesia can also bring wiretapping cases to the International Court of Justice because the Defense Signals Directorate (DSD) is the Australian government's official intelligence agency. The behavior of relations between countries and tapping as done by Australia to Indonesia appears to have shifted the meaning no longer as a crime but rather a violation of the diplomatic code of ethics.

Keywords: Legal Protection; Tapping; Indonesia; Australia

Journal Homepage http://ijssr.net/index.php/ijssr

This is an Open Access article under the CC BY SA license

https://creativecommons.org/licenses/by-sa/4.0/

Published by Indonesian Academy of Social and Religious Research

\section{Introduction}

The wiretapping activities carried out by Australia to Indonesia made Indonesia realize that there was a gap that had been forgotten so far, namely Indonesia's national security. The Indonesian state, as well as land, sea, and air, does not yet have the awareness to unite opinions on how to regulate Indonesia's security. The issue of wiretapping has often appeared in political and legal debates among politicians or law enforcers and academics in Indonesia recently. At least wiretapping has been considered as a powerful tool that is expected to be able to reveal or at least unmask the existence of organized crime. Also, according to some circles, it can prevent crimes against national security. However, certain parties also use wiretapping for negative things that could potentially harm the victim. Even in its development, tapping is not only information related to individual 
personal interests, because currently, classified information of a country can also become the object of wiretapping. The increasingly sophisticated development of the intelligence world requires diplomatic agents of each country to be more careful in their attitudes and actions to maintain harmonious relations between countries. There is an interesting issue that prompts the need for a study on wiretapping. News about this wiretapping was leaked by a former cybersecurity contractor who worked for the United States national security agency whose idealism was enforce confidentiality rights in communicating through technology platforms communication such as cellular telephones or through information technology channels, namely the internet. Edward Snowden, a figure who revealed about the existence of wiretapping carried out by Australia to Indonesia, said that the wiretapping was carried out at the request of the United States and assisted by Singapore by taking a position or base camp in foreign embassies such as the Australian embassy, tapping the cellular phone belonging to the President of Indonesia along with his wife and also several state figures such as former ministers or ministers. They are still active in the government. The data provided by Edward Snowden was information on wiretapping by the Australian Intelligence Directorate, which had been carried out since 2009, meaning that Indonesia was currently or was about to face a presidential election, and it is suspected that it is still being carried out today. As a result, President SBY temporarily withdrew the Indonesian Ambassador from Canberra and debated several collaborations in handling people smuggling policies and military cooperation. ${ }^{1}$ (R. Aj. Rizka Februari Prabaningtyas 2013)

Based on various reasons and interests to make aware of the need for national security in the field of information and as lessons learned from the case of wiretapping by Australia against the President of Indonesia and several Indonesian officials, researchers raised the issue of State protection against Indonesia's national security in terms of international law with a case study of Indonesian wiretapping by Australia. Yielded positive results in the presence of several cases of arrests. However, the development of this regulation concerning wiretapping needs to be carefully scrutinized so as not to curb the freedom of citizens.

1 R. Aj. Rizka Februari Prabaningtyas, S.IP. 2013. "Indonesia-Australia: Menguji Persahabatan Di Tengah Konflik Penyadapan." Institue of International Studies Universitas Gadjah Mada 20 (1): 2 


\section{Formulation of the problem}

This journal will discuss how the legal protection against Indonesia regarding tapping cases by Australia

Then formulated the problem:

1) Principles of the Prohibition of Tapping in International Law and Human Rights

2) The Principle of the Prohibition of Tapping in National Law

3) Legal Protection in the Case of Australia-Indonesia Tapping

4) Legal Efforts by the Government of Indonesia in the Australian Tapping Case against Indonesia

5) Impact of Transnational Tapping on International Relations

\section{Research Methods}

This journal uses yuridical reviewing research methodology normative. Normative legal research is carried out by analyzing the synthesis of deductive conclusions from the statements contained in data sources such as library materials including journals, books, documents, literature or secondary legal practice such as laws, legal theory, court decisions, expert opinions relevant and related to the issues discussed in this journal. The approaches used include statutory, conceptual, and analytical approaches. This research is a prescriptiveanalytical which data synthesis, discussion, and conclusions are analyzed in the form of qualitative research. ${ }^{2}$ (Ibrahim 2006)

\section{Results And Discussion}

\section{A. Principles of the Prohibition of Tapping in International Law and Human Rights}

Tapping is usually defined as listening without the consent of the person concerned through tapping or other electronic media. According to Amanda Hale, interception, namely someone who intercepts information during transmission, is a result of interference made through the system or transmission monitoring, content that is obtained online, when it is being sent to someone else or when the

2 Ibrahim, Johnny. 2006. Teori E Metodologi Penelitian Hukum Normatif. Teori Metodologi Penelitian A. 
recipient of the information receives it. ${ }^{3}$ (Amanda Hale and John Edwards 2006) Tapping is defined as the context of communication carried out online in various formats. Communication can be done using text messages, email, fax, telephone, etc. ${ }^{4}$ (Jeffrey B. Welty 2009). Tapping is an action that is not allowed by various regulations. Every individual according to Article 12 of the Universal Declaration of Human Rights (UDHR) 1948, has the right to obtain legal protection against interference or attack on privacy, family, home, or other private domains. According to article 17 of the International Covenant on Civil and Political Rights (ICCPR) of 1966, it says that every individual should not be the target of violating the law to privacy or other personal rights. And every individual has the same right to legal protection so as not to get interference or attacks from other parties. General Comment number 16 regarding article 17 of the ICCPR above, which was approved by the UN at its twenty-third session in 1988, that this matter must be conveyed to that person without being read or seen by other parties. Cell phone tapping and other means of communication or recordings of speech are not permitted. ${ }^{5}$ (Supriyadi Widodo Eddyono \& Erasmus A. T. Napitupulu 2013)

Every individual has the right to respect the privacy of each person and his family, as stipulated in article 8 of Clause 1 of the European Convention for the Protection of Human Rights and Fundamental Freedoms in 1958. The prohibition on wiretapping also applies to official and diplomatic offices. The recipient country is obliged to give permission and also protect the communications made, which is also its official purpose, and also when using wifi must have the consent of that country according to Article 27 Clause 1 of the Vienna Convention existed in 1961. Further discussed in Clause 2, the domain of purpose of the exchange process information (mission) should not be contested by all parties because this is a privilege and diplomatic immunity. The prohibition against wiretapping and sabotage of information is based on the events of 1215. It is contained in the Magna Charta convention with the initial aim of providing legal protection for every individual whose rights are violated. The further application of this regulation explains that no individual has the right and can be justified in terms

3 Amanda Hale and John Edwards. 2006. "Getting Its Tapped." Computer and Communication Law Review.

4 Jeffrey B. Welty. 2009. "Prosecution and Law Enfercement Access to Information about Electronic Communication." Administration of Justice Bulletin 5: 8.

5 Supriyadi Widodo Eddyono \& Erasmus A.T.Napitupulu. 2013. Komentar Atas Pengaturan Penyadapan Dalam Rancangan KUHAP. Jakarta: Institue for Criminal Justice Reform. 
of depriving people of life, individual freedom to own property, or communicate without going through a recognized legal process, even though this regulation binds legal subjects as high as the state. ${ }^{6}$ (Indonesia Legal Center Publishing 2006)

\section{B. Principles of the Prohibition of Tapping in National Law}

In Indonesia, the protection of the right to privacy has only become widely known after the amendments to the 1945 Constitution, however, this provision is regulated more clearly in Article 551 of the Criminal Code, which explains that individuals who do not have a permit to enter a land area can be subject to criminal penalties of two hundred and twenty-five rupiahs. ${ }^{7}$ (Supriyadi Widodo Eddyono \& Erasmus A. T. Napitupulu 2013).

The fourth amendment of the 1945 Constitution also guarantees the right to privacy by explaining that every person has the right to protection of himself, family, honor, dignity, and property under his control, and the right to a sense of security and protection from all forms of threats. All rights guaranteed in the 1945 Constitution include the basic or main rights of all citizens. Freedom and confidentiality between individuals is part of human rights by Article 32 No. 39 of 1999, which explains that the freedom to exchange information and the confidentiality of the conversation must not be contested, either electronically or non-electronically, unless the wiretapping is an illegal act whose mechanism is carried out through a judicial process and a judge's order. Each individual by Article 40 of Law no. 36 of 1999 may not intercept information in any form that can be spread over the telecommunications network. In this article, it is explained that the installation of tools or additional devices, including wiretapping, is to obtain information that should not be known. Usually, this information is private information that should not be known by others.

Regulations regarding the exchange of information and electronic or online transactions are regulated more clearly in Article 31 clause 1 Number 11 of 2000, which formulates and regulates each individual who deliberately commits the act of wiretapping without giving the individual rights from the authorized party is

6 Indonesia Legal Center Publishing. 2006. Undang-Undang No. 39 Tahun 1999 Tentang Hak Asasi Manusia. Jakarta: ILCP

7 Supriyadi Widodo Eddyono \& Erasmus A.T.Napitupulu. 2013. Komentar Atas Pengaturan Penyadapan Dalam Rancangan KUHAP. Jakarta: Institue for Criminal Justice Reform. 
an act that violates the law and further in Clause 2 it is explained that all forms of wiretapping whether with or without other purposes such as making changes, deleting, terminating electronic information, or electronic documents that are being sent against forms of information that are not public or not public (state secrets) are an act against the law too. ${ }^{8}$

\section{Legal Protection in the Australia-Indonesia Tapping Case}

Tapping is an act of listening to, recording, modifying, obstructing, and / or recording the transmission of electronic information that is not public in nature, either using a communication cable network or a wireless network. ${ }^{9}$ (Kristin S.H 2013). Australia already has clear and detailed laws governing wiretapping. On December 1, 2014, Australia passed the "Telecommunications (Interception and Access) Act 1979," which specifically regulates the prohibition of telecommunications tapping. ${ }^{10}$ (Legistation 1979)

The issue of wiretapping is also regulated in international law, particularly diplomatic law. In Article 3 paragraph (1) letter d of the 1961 Vienna Convention on Diplomatic Relations, it is stated that the delegation of the sending country can report the development and condition of the receiving country by any legal means. However, if the security and sovereignty of the receiving country are disturbed because the sending country takes the information with tapping, this is prohibited in the provisions of international law. ${ }^{11}$ (Mohammad Shoelhi 2001).

Furthermore, Article 45 of the 1961 Vienna Convention also states that a state building located in a country cannot be contested, which in essence involves two aspects. The first aspect concerns the obligations of the receiving country to provide full protection for foreign representatives in the country from any disturbances. ${ }^{12}$ (Sumaryo Suryokusumo 2005).

In the event of an extraordinary thing, such as armed conflict and a break in diplomatic relations between the two countries, the receiving country should protect the representative building with its properties and archives. Second, the

Ibid. Hlm. 9-10

9 Kristian S.H. 2013. Sekelumit Tentang Penyadapan Dalam Hukum Positif Di Indonesia. Bandung: Nuansa Aulia.

10 Legistation, Federal Register of. 1979. "Telecommunications (Interception and Access) Act 1979.” 1979. http://www.comlaw.gov.au/Details/C2014C00786/Html/Text.

11 Mohammad Shoelhi. 2001. Diplomasi Praktik Komunkas Internasional. Bandung: Simbiosa Rekatama Media.

12 Sumaryo Suryokusumo. 2005. Hukum Diplomatik Teori Dan Kasus. Bandung: PT Alumni. 
position of the foreign representative itself, which is declared immune from inspection, includes his belongings and all the files in therein. ${ }^{13}$

Apart from international law, there is Indonesian national law that regulates wiretapping, namely Article 31 of Law Number 11 of 2008 concerning Electronic Information and Transactions (UU ITE), which states that tapping carried out without rights or against the law is prohibited. Meanwhile, Article 47 of the same law states that everyone who meets the elements contained in Article 31 can be subject to imprisonment ten years and/or a fine of eight hundred million rupiahs. Apart from the ITE Law, tapping of information in any form is also prohibited under Article 40 of Law Number 36 the Year 1999 concerning Telecommunications. Furthermore, Article 56 of the Telecommunication Law also includes criminal sanctions. If a person is proven to have committed wiretapping, he will be subject to a maximum imprisonment of fifteen years.

\section{Legal Efforts by the Government of Indonesia in Cases Australian wiretapping of Indonesia}

Two forms of legal remedies can be taken by Indonesia, namely preventive legal measures and repressive legal measures. Preventive legal measures are efforts to avoid or prevent violations from recurring. ${ }^{14}$ (Vollmar HFA 1996). In this case, Indonesia can take preventive legal measures bilaterally to avoid or prevent violations involving two parties. In this case, Indonesia has signed a Code of Conduct on Framework for Security Cooperation with Australia, which agrees not to do so actions that may harm the interests of certain parties, including wiretapping. ${ }^{15}$ (Kompas.com 2014)

Repressive remedies are actions when a rule has been violated. ${ }^{16}$ (Vollmar HFA 1996). Multilateral repressive remedies are the last legal remedies given when a dispute has occurred involving more than two parties. If it is linked to the Australian wiretapping case, Indonesia can bring this case to the International Court of Justice (ICJ). Indonesia must be able to ensure that it is a state organ or agent of the state that carries out wiretapping. ${ }^{17}$ (Inside International Justice 2013)

13 Ibid.

14 Vollmar HFA. 1996. Pengantar Studi Hukum Perdata. Jakarta: Rajawali Press.

15 Kompas.com. 2014. "Code of Conduct'Ditandatangani,Indonesia-Australia Sepakat Tak Menyadap." 2014

16 Vollmar HFA. 1996. Pengantar Studi Hukum Perdata. Jakarta: Rajawali Press.

17 Inside International Justice. 2013. “Negara Bisa Bawa Kasus Penyadapan Ke ICJ.” 2013. 
The Defense Signals Directorate (DSD) is an intelligence agency belonging to the Australian government ${ }^{18}$ (Australian Signals Directorate, n.d.), or in other words, the Defense Signals Directorate (DSD) is one of the Australian state organs. ICJ, as an international organization, has the authority to resolve the Australian wiretapping case against Indonesia. Article 34 paragraph (1) of the ICJ Statute states: "Only states may be parties in cases before the Court." Based on these provisions, Indonesia can submit Australian wiretapping cases to the International Court of Justice.

\section{E. Impact of Transnational Tapping on International Relations}

Violation of international law as a form of interaction between countries is something that often occurs. The wiretapping case committed by Australia against Indonesia and America against Germany is a small example of violations of international law in today's digital era. Viewed from the context of public international law, dispute resolution methods that are resolved by violence, war, invasion as a form of revenge are classic international legal settlement methods since the birth of the Hague Peace Conference 1899 and 1907, which later gave birth to the convention on the Pacific Settlement of International. However, because of its recommendation and non-binding nature, the convention does not have the force to prohibit countries from engaging in violence as a method of dispute resolution. ${ }^{19}$ (Huala Adolf 2004).

However, over time, knowledge and technology were born international organizations that gave birth to more civilized agreements and dispute resolution mechanisms. It cannot be denied that this incident resulted in the strained relationship between Australia and Indonesia. It has also set a bad precedent for Australia towards the international community in conducting diplomatic relations. The first impact was the withdrawal of the Indonesian ambassador to Australia to explain the matter and progress of the wiretapping case. ${ }^{20}$ (NN 2013).

The next impact was the suspension of cooperation with Australia in the form of intelligence and the Human Smuggling Task Force (Satgas People Smuggling), joint marine patrols in southern Indonesia to handle asylum (Asylum Seekers), and joint military exercises between the two countries. ${ }^{21}$ (NN, n.d.) Besides, the

18 Australian Signals Directorate. n.d. "About ASD." http://www.asd.gov.au/about/index.htm.

19 Huala Adolf. 2004. Hukum Penyelesaian Sengketa. Jakarta: Sinar Grafika.

20 NN. 2013. "Dubes Indonesia Akan Dipanggil Pulang Dari Australia." 2013. http://www.bbc.co.uk/ indonesia/berita_indonesia/2013/11/131118_reaksi_penyadapan.shtml,

21 NN. n.d. "TNI Hentikan Kerja Sama Militer Dengan Australia." 2013. https://www.bbc.com/ indonesia/berita_indonesia/2013/11/131121_kemenhan_kerjasama_militer_dihentikan. 
Indonesian government feels the need to review several policies and agreements concerning important relations between Indonesia and Australia. Australia itself, on the other hand, issued a travel warning to its citizens to travel to Indonesia.

\section{CONCLUSION}

Tapping is an activity of installing additional tools or equipment on telecommunication networks to obtain information by illegal means. Juridically tapping is an act prohibited under international law and human rights-based on Article 12 of the Universal Declaration of Human Rights (UDHR) 1948, Article 17 of the International Covenant on Civil and Political Rights (ICCPR) 1966. The Human Rights Committee of the United Nations (UN) at the twenty-third trial of 1988, prohibiting the practice of wiretapping as regulated by diplomatic offices and officers. The prohibition also exists in Article 8 paragraph (1), the European Convention for the Protection of Human Rights and Fundamental Freedoms (1958) and Article 27 (1) of the 1961 Vienna Convention regarding the prohibition of wiretapping of diplomatic offices and officers, as well as prohibitions related to the Due Process of Law, both for individual secret rights (basic fundamental rights) and immunity rights for diplomatic corp. Within the framework of national law, the prohibition of wiretapping is contained in Article $28 \mathrm{G}$ paragraph (1) of the 1945 Constitution, Article 32 of Law no. 39 of 1999 concerning Human Rights, Article 40 of Law No. 36 of 1999 concerning Telecommunications, Article 31 paragraph (1) of Law no. 11 of 2008 concerning Information and Electronic Transactions, and Article 31 paragraph (2) of Law no. 11 of 2008 on Information and Electronic Transactions. In international law, Indonesian national law and Australian law prohibits wiretapping. Indonesia has signed the Code of Conduct on Framework for Security Cooperation to prevent wiretapping. Also, Indonesia can bring wiretapping cases to the International Court of Justice because the Defense Signals Directorate (DSD) is the Australian government's official intelligence agency. The behavior of relations between countries and tapping as done by Australia to Indonesia appears to have shifted the meaning no longer as a crime but rather a violation of the diplomatic code of ethics.

\section{Conflict of Interest}

The authors declared that they have no conflicts of interest. 
Hanna Wijaya, Yohanes Firmansyah, Yana Sylvana, Michelle Angelika S

\section{Acknowledgments}

A big thank you to Diani Sadiawati, SH, LLM, PhD from the Department of International Law Pembangunan Nasional Veteran Jakarta University for guiding us in international law courses

\section{Author Contribution}

Hanna Wijaya played a role in sparking research ideas and making the manuscript. Yohanes Firmansyah contributed in making the manuscript and translating the language. Yana Sylvana was in charge of finding journal compilation material. Michelle Angelika $\mathrm{S}$ contributed to arranging the writing format and revising the manuscript

\section{References}

Amanda Hale and John Edwards. 2006. "Getting Its Tapped." Computer and Communication Law Review.

Australian Signals Directorate. n.d. "About ASD." http://www.asd.gov.au/about/ index.htm.

Huala Adolf. 2004. Hukum Penyelesaian Sengketa. Jakarta: Sinar Grafika.

Ibrahim, Johnny. 2006. Teori \& Metodologi Penelitian Hukum Normatif. Teori Metodologi Penelitian A.

Indonesia Legal Center Publishing. 2006. Undang-Undang No. 39 Tahun 1999 Tentang Hak Asasi Manusia. Jakarta: ILCP.

Inside International Justice. 2013. "Negara Bisa Bawa Kasus Penyadapan Ke ICJ.” 2013.

Jeffrey B. Welty. 2009. "Prosecution and Law Enfercement Access to Information about Electronic Communication."'Administration of Justice Bulletin 5: 8.

Kompas.com. 2014. “'Code of Conduct' Ditandatangani, Indonesia-Australia Sepakat Tak Menyadap.” 2014.

Kristin S.H.2013. Sekelumit Tentang Penyadapan Dala Hukum PositifDi Indonesia. Bandung: Nuansa Aulia.

Legistation, Federal Register of. 1979. "Telecommunications (Interception and Access) Act 1979.” 1979. http://www.comlaw.gov.au/Details/ C2014C00786/Html/Text. 
Mohammad Shoelhi. 2001. Diplomasi Praktik Komunkas Internasional. Bandung: Simbiosa Rekatama Media.

NN. n.d. "TNI Hentikan Kerja Sama Militer Dengan Australia." 2013. https:// www.bbc.com/indonesia/berita_indonesia/2013/11/131121_kemenhan_ kerjasama_militer_dihentikan.

. 2013. "Dubes Indonesia Akan Dipanggil Pulang Dari Australia." 2013. http://www.bbc.co.uk/indonesia/berita_indonesia/2013/11/131118_ reaksi_penyadapan.shtml,.

R. Aj. Rizka Februari Prabaningtyas, S.IP. 2013. “Indonesia-Australia: Menguji Persahabatan Di Tengah Konflik Penyadapan." Institue of International Studies Universitas Gadjah Mada 20 (1): 2.

Sumaryo Suryokusumo. 2005. Hukum Diplomatik Teori Dan Kasus. Bandung: PT Alumni.

Supriyadi Widodo Eddyono \& Erasmus A. T. Napitupulu. 2013. Komentar Atas Pengaturan Penyadapan Dalam Rancangan KUHAP. Jakarta: Institue for Criminal Justice Reform.

Vollmar HFA. 1996. Pengantar Studi Hukum Perdata. Jakarta: Rajawali Press. 